Article

\title{
Antiproliferative Activity of (-)-Rabdosiin Isolated from Ocimum sanctum L.
}

\author{
Alexandros Flegkas ${ }^{1}$, Tanja Milosević Ifantis ${ }^{1}$, Christina Barda ${ }^{1}$, Pinelopi Samara ${ }^{2}$, \\ Ourania Tsitsilonis ${ }^{2}$ and Helen Skaltsa ${ }^{1, *}$ \\ 1 Department of Pharmacognosy and Chemistry of Natural Products, Faculty of Pharmacy, National and \\ Kapodistrian University of Athens, Panepistimiopolis, Zografou, 15771 Athens, Greece; \\ alexflegas@yahoo.com (A.F.); kgtanja@yahoo.com (T.M.I.); cbarda@pharm.uoa.gr (C.B.) \\ 2 Department of Biology, National and Kapodistrian University of Athens, Panepistimiopolis Zografou, \\ 15784 Athens, Greece; psamara@biol.uoa.gr (P.S.); rtsitsil@biol.uoa.gr (O.T.) \\ * Correspondence: skaltsa@pharm.uoa.gr
}

Received: 31 January 2019; Accepted: 7 March 2019; Published: 12 March 2019

check for updates

\begin{abstract}
Background: Ocimum sanctum L. (holy basil; Tulsi in Hindi) is an important medicinal plant, traditionally used in India. Methods: The phytochemical study of the nonpolar (dichloromethane 100\%) and polar (methanol:water; 7:3) extracts yielded fourteen compounds. Compounds 6, 7, 9, 11, 12, and 13, along with the methanol:water extract were evaluated for their cytotoxicity against the human cancer cell lines MCF-7, SKBR3, and HCT-116, and normal peripheral blood mononuclear cells (PBMCs). Results: Five terpenoids, namely, ursolic acid (1), oleanolic acid (2), betulinic acid (3), stigmasterol (4), and $\beta$-caryophyllene oxide (5); two lignans, i.e., (-)-rabdosiin (6) and shimobashiric acid C (7); three flavonoids, luteolin (8), its 7-O- $\beta$-D-glucuronide (9), apigenin 7-O- $\beta$-D-glucuronide (10); and four phenolics, (E)-p-coumaroyl 4-O- $\beta$-D-glucoside (11), 3-(3,4-dihydroxyphenyl) lactic acid (12), protocatechuic acid (13), and vanillic acid (14) were isolated. Compound 6 was the most cytotoxic against the human cancer lines assessed and showed very low cytotoxicity against PBMCs. Conclusions: Based on these results, the structure of compound $\mathbf{6}$ shows some promise as a selective anticancer drug scaffold.
\end{abstract}

Keywords: Ocimum sanctum; Lamiaceae; (-)-rabdosiin; cytotoxic activity; triterpenoids; phenolic derivatives

\section{Introduction}

Indigenous to India and parts of North and Eastern Africa, China, Hainan Island, and Taiwan, Tulsi (Ocimum sanctum L.; syn. Ocimum tenuiflorum L.) is referred to as "the elixir of life" or "the queen of herbs" and is believed to promote longevity [1,2]. Various parts of the plant are used in Ayurveda and Siddha traditional medicine to treat coughs, bronchitis, fever, bile disturbances, and has been also used as an anthelminthic, antiemetic, anticancer, antiseptic, antioxidant, antidiabetic anti-inflammatory, antiulcer, hepatoprotective, cardioprotective, anticoagulant, anticataract, and analgesic agent. Additionally, it has been reported that extracts of the plant can serve as vitalizers and rejuvenators, and are thought to increase life-expectancy and promote disease-free living [3-17].

Despite its wide therapeutic range, special care should be taken in case of the use of Tulsi in conjunction with other prescribed medicines since it exhibits various drug interactions. For example, its concomitant use with anticoagulants, such as heparin, warfarin, aspirin, clopidogrel, etc., is contraindicated due to allergic reactions that may occur. In addition, Tulsi increases the activity of phenobarbital and consequently may stimulate uterine contractions; thus, its use during pregnancy and lactation is not recommended [18,19]. 
The genus Ocimum L. is abundant in methylated flavones of the apigenin and luteolin types: cirsimartin, cirsilineol, isothymusin, and isothymonin. Terpenes such as triterpenic acids, ursolic, oleanolic acids, the oxygenated monoterpene carvacrol, the sesquiterpene hydrocarbon caryophyllene, the phenylpropenes eugenol and its methyl ether, as well as caffeic and rosmarinic acid are also present in significant amounts s. According to literature data, O. sanctum contains flavonoids, phenolics, neolignans, tannins, triterpenoids, sterols, cerebrosides, alkaloids, and saponin; most of them are well known for their in vitro and in vivo biological activities, such as antioxidant or prooxidant, cytotoxic, antitumor, anticarcinogenic, hepatoprotective, anti-inflammatory, as well as antiviral [3-6,19-23]. Moreover, the essential oil of $O$. sanctum contains high amount of eugenol $(70 \%)$, also known for its antioxidant, anti-inflammatory, antimicrobial, and cytotoxic activities [24,25].

Based on the above, the plant is of high pharmacological importance, although it is still not fully chemically investigated. In this study, we analyzed both nonpolar and polar extracts of $O$. sanctum and studied the cytotoxic activity of its secondary metabolites.

\section{Materials and Methods}

\subsection{Plant Material}

Aerial parts of O. sanctum L. were collected in flowering stage at Suriname, as previously described [21]. A voucher specimen (ATHS 093) has been deposited in the Herbarium of the Laboratory of Pharmacognosy, National and Kapodistrian University of Athens.

\subsection{General Experimental Procedures}

${ }^{1} \mathrm{H},{ }^{13} \mathrm{C}$, and 2D NMR spectra were recorded in $\mathrm{CDCl}_{3}$ and $\mathrm{CD}_{3} \mathrm{OD}$ on Bruker DRX 400 and Bruker AC $200\left(50.3 \mathrm{MHz}\right.$ for ${ }^{13} \mathrm{C}$ NMR) instruments at $295 \mathrm{~K}$. Chemical shifts are given in ppm $(\delta)$ and were referenced to the solvent signals at 7.24/3.31 and 77.0/49.0 ppm for ${ }^{1} \mathrm{H}-/{ }^{13} \mathrm{C}-\mathrm{NMR}$, respectively. COSY, HSQC, HMBC, HSQC-TOCSY (Heteronuclear Single Quantum Coherence-Total Correlation Spectroscopy), NOESY, and ROESY (Rotating-frame nuclear Overhauser Effect correlation SpectroscopY; mixing time $950 \mathrm{~ms}$ ) were performed using standard Bruker microprograms. The solvents used were of spectroscopic grade (Merck). The $[\alpha]_{D}^{20}$ values were obtained in $\mathrm{CHCl}_{3}$ or $\mathrm{MeOH}$ on a Perkin-Elmer 341 Polarimeter. FT-IR spectra were recorded on a Perkin Elmer PARAGON 500 spectrophotometer. UV spectra were recorded on a Shimadzu UV-160 A spectrophotometer according to Mabry et al. (1970) [26]. GC-MS analyses were performed on a Hewlett-Packard 5973-6890 system operating in EI mode $(70 \mathrm{eV})$ equipped with a split/splitless injector $\left(220^{\circ} \mathrm{C}\right)$, a split ratio $1 / 10$, using a fused silica HP-5 MS capillary column ( $30 \mathrm{~m} \times 0.25 \mathrm{~mm}$ (i.d.), film thickness: $0.25 \mu \mathrm{m})$ with a temperature program for HP-5 MS column from $60{ }^{\circ} \mathrm{C}(5 \mathrm{~min})$ to $280{ }^{\circ} \mathrm{C}$ at a rate of $4{ }^{\circ} \mathrm{C} / \mathrm{min}$ and helium as a carrier gas at a flow rate of $1.0 \mathrm{~mL} / \mathrm{min}$. Vacuum liquid chromatography (VLC): silica gel 60H (Merck, Art. 7736) [27]. Column chromatography (CC): silica gel (Merck, Darmstadt, Germany, Art. 9385), gradient elution with the solvent mixtures indicated in each case. Preparative thin layer chromatography (pTLC) was performed on silica gel (Merck, Art. 5721) and cellulose (Merck, Art. 5716). MPLC (Medium Pressure Liquid Chromatography) support: reversed-phase column (Merck, 10167): $36 \times 3.6 \mathrm{~cm}$ (Büchi Borosilikat 3.3, Code 19674), $24 \times 1.5 \mathrm{~cm}$ (Büchi Borosilikat 3.3, Code 2813) on a system (Büchi Pump C-615). HPLC (High Performance Liquid Chromatography) support: preparative HPLC was performed using (a) Kromasil 100 si Semi-prep $25 \mathrm{~cm} \times 10 \mathrm{~mm}$ and (b) Kromasil $C_{18} 25 \mathrm{~cm} \times 10 \mathrm{~mm}$ columns on a HPLC system (Jasco PU-2080) equipped with a RI detector (Shimadzu 10 A). Fractionation was always monitored by TLC silica gel 60 F-254, (Merck, Art. 5554) with visualization under UV (254 and $365 \mathrm{~nm}$ ) and spraying with vanillin-sulfuric acid reagent (vanillin Merck, Art. No. S26047 841) and with Neu's reagent for phenolics [28]. 


\subsection{Extraction and Isolation}

The initial extraction was previously described [21]. In brief, the aerial parts of O. sanctum L. $(0.40 \mathrm{~kg})$ were air-dried and finely ground, and then extracted at room temperature using dichloromethane and methanol, successively.

Part of the dichloromethane residue (11.9 g) was re-extracted at room temperature with ethyl acetate (EtOAc) and $n-\mathrm{BuOH}$, yielding two fractions (A and B). Fraction A (7.8 g) was fractionated by VLC on silica gel using mixtures of cyclohexane and EtOAc of increasing polarity (100:0; 90:10; 80:20; 70:30; 60:40; 50:50; 40:60; 30:70) and yielded 8 subfractions $\left(\mathrm{A}_{1}-\mathrm{A}_{8}\right)$. Subfractions $\mathrm{A}_{3}$ (eluted with cyclohexane:EtOAc 80:20) and $\mathrm{A}_{4}$ (eluted with cyclohexane:EtOAc 70:30) were combined to group AA (401.7 mg), subjected to CC over silica gel using mixtures of cyclohexane and EtOAc and yielded 81 fractions combined to 11 groups $\left(\mathrm{AA}_{1}-\mathrm{AA}_{11}\right)$. Purification on preparative TLC of fraction $\mathrm{AA}_{3}$ (51.8 mg; eluted with cyclohexane:EtOAc 95:5) yielded compound 5 (1.3 mg). Fractions AA 6 (34.7 mg; eluted with cyclohexane:EtOAc 97:3) and $\mathrm{AA}_{8}(34.4 \mathrm{mg}$; eluted with cyclohexane:EtOAc 85:15) were further fractionated by normal-phase HPLC (isocratic elution cyclohexane:EtOAc 75:25) and yielded compounds $4\left(t_{R} 21.84 \mathrm{~min} ; 3.2 \mathrm{mg}\right), 2\left(t_{R} 16.01 \mathrm{~min} ; 1.7 \mathrm{mg}\right)$, and $3\left(t_{R} 14.84 \mathrm{~min} ; 5.5 \mathrm{mg}\right)$. Fraction B purified by $\mathrm{CC}$ on silica gel using mixtures of cyclohexane and EtOAc yielded 131 fractions combined to 18 groups $\left(\mathrm{B}_{1}-\mathrm{B}_{18}\right)$. Fraction $\mathrm{B}_{5}$ (eluted with cyclohexane:EtOAc 80:20) was identified as compound $1(1.8 \mathrm{mg})$, while fraction $\mathrm{B}_{8}$ (eluted with cyclohexane:EtOAc 70:30) as compound $14(2.3 \mathrm{mg})$.

Part of the methanol residue ( $3.6 \mathrm{~g}$ ) was subjected to $\mathrm{RP}_{18}-\mathrm{MPLC}$ using a $\mathrm{H}_{2} \mathrm{O}: \mathrm{MeOH}$ gradient system (100:0; 90:10; 85:15; 80:20; 75:25; 50:50; 0:100; 0:100; 50 min each) and yielded 8 fractions $\left(\mathrm{M}_{1}-\mathrm{M}_{8}\right)$. Group $\mathrm{M}_{2}$ (eluted with $\mathrm{H}_{2} \mathrm{O}: \mathrm{MeOH}$ 90:10) was applied to $\mathrm{CC}$ on silica gel with mixtures of dichloromethane:methanol:water of increasing polarity to give 151 fractions (combined to 14 groups; $\left.\mathrm{M}_{2-1}-\mathrm{M}_{2-14}\right)$ and afforded compounds 13 ( $\mathrm{M}_{2-5}$ eluted with DM:MeOH: $\mathrm{H}_{2} \mathrm{O}$ 95:5:0.3; $\left.40.5 \mathrm{mg}\right), 11$ ( $\mathrm{M}_{2-11}$ eluted with DM:MeOH: $\mathrm{H}_{2} \mathrm{O}$ 70:30:3; $\left.1.6 \mathrm{mg}\right)$, and $12\left(\mathrm{M}_{2-12} ; 4.3 \mathrm{mg}\right.$; eluted with DM:MeOH: $\mathrm{H}_{2} \mathrm{O}$ 40:60:6). $\mathrm{M}_{3}$ (290.0 mg) was further purified on Sephadex LH-20 eluted with $\mathrm{MeOH} \mathrm{(100 \% )} \mathrm{and} \mathrm{yielded}$ 30 fractions combined in 10 subfractions $\left(\mathrm{M}_{3-1}-\mathrm{M}_{3-10}\right) . \mathrm{M}_{3-6}(57.0 \mathrm{mg})$ was subjected to reversed-phase HPLC (isocratic elution; methanol:AcOH 5\% 7:3) to give compounds $6\left(t_{R} 23.90 \mathrm{~min} ; 7.5 \mathrm{mg}\right), 9\left(t_{R}\right.$ $29.30 \mathrm{~min} ; 1.9 \mathrm{mg})$, and $7\left(t_{R} 35.20 \mathrm{~min} ; 3.7 \mathrm{mg}\right) . \mathrm{M}_{6}(674.2 \mathrm{mg})$ was similarly fractionated by CC over silica gel with mixtures of $\mathrm{CH}_{2} \mathrm{Cl}_{2}: \mathrm{MeOH}: \mathrm{H}_{2} \mathrm{O}$ of increasing polarity and yielded 135 fractions combined in 25 subgroups $\left(\mathrm{M}_{6-1}-\mathrm{M}_{6-25}\right)$. Subgroup $\mathrm{M}_{6-24}$ (eluted with $\mathrm{CH}_{2} \mathrm{Cl}_{2}: \mathrm{MeOH}: \mathrm{H}_{2} \mathrm{O}$ 70:30:3; $69.4 \mathrm{mg}$ ) was subjected to CC on silica gel as previously described to give 75 fractions; fraction 8 (1.3 $\mathrm{mg})$ was identified as compound 10. Another part of the methanol extract $(7.7 \mathrm{~g})$ was redissolved in water and extracted at room temperature with EtOAc and $n-\mathrm{BuOH}$, affording three fractions (MA-MC). $\mathrm{MB}$ (eluted with $n$-BuOH; $5.3 \mathrm{~g}$ ) was subjected to $\mathrm{RP}_{18}-\mathrm{MPLC}$ using a $\mathrm{H}_{2} \mathrm{O}: \mathrm{MeOH}$ gradient system $\left(100 \% \mathrm{H}_{2} \mathrm{O} \rightarrow 100 \% \mathrm{MeOH}\right.$; steps of $\left.10 \% \mathrm{MeOH}\right)$ and yielded 11 fractions $\left(\mathrm{MB}_{1}-\mathrm{MB}_{10}\right)$. Fraction $\mathrm{MB}_{3}$ (eluted with $\mathrm{H}_{2} \mathrm{O}: \mathrm{MeOH}$ 80:20) was identified as compound 8 (13.6 mg).

It is notable that during the fractionation and isolation procedures, all extracts and subfractions were continuously monitored by analytical TLC and ${ }^{1} \mathrm{H}-\mathrm{NMR}$. All obtained fractions were concentrated to dryness under vacuum $\left(30^{\circ} \mathrm{C}\right)$ and placed in activated desiccators with $\mathrm{P}_{2} \mathrm{O}_{5}$ until their weights were stabilized.

\subsection{Cytotoxic Effects against Cancer Cell Lines}

The cytotoxic activity of the compounds, as well as of the initial methanol extract, were tested against three human cancer cell lines: MCF-7 (breast; estrogen receptor positive (ER+), progesterone receptor (PR)+, and HER2 negative (-)), SKBR3 (breast; ER-, PR-, and HER2+), and HCT-116 (colon). All cell lines were maintained in RPMI-1640, supplemented with 10\% heat-inactivated fetal bovine serum (FBS), $10 \mathrm{mM}$ Hepes, $10 \mathrm{U} / \mathrm{mL}$ penicillin, $10 \mathrm{U} / \mathrm{mL}$ streptomycin, and $5 \mathrm{mg} / \mathrm{mL}$ gentamycin (all from Lonza, Cologne, Germany) (thereafter referred to as complete medium) at $37^{\circ} \mathrm{C}$ in a humidified $5 \% \mathrm{CO}_{2}$ incubator. 
Compounds were prepared at a stock solution of $10.0 \mathrm{mg} / \mathrm{mL}$ in DMSO and the extract at $20.0 \mathrm{mg} / \mathrm{mL}$ in DMSO. Prior to their use, they were diluted in plain RPMI-1640. Cytotoxicity was evaluated by the MTT reduction assay [29], which determines the effect of treatment with an exogenously added agent on the viability of the cell population. Briefly, cells were plated in 96-well plates (Greiner Bio-One GmbH, Frickenhausen, Germany; $5 \times 10^{3}$ cells/well) and incubated at $5 \% \mathrm{CO}_{2}$ and $95 \%$ air at $37^{\circ} \mathrm{C}$ for $24 \mathrm{~h}$, in order to adhere. Further, cells were incubated with the compounds for $72 \mathrm{~h}$ at $37^{\circ} \mathrm{C}$ in a $5 \% \mathrm{CO}_{2}$ incubator. The MTT reagent (Sigma-Aldrich, Darmstadt, Germany; $1 \mathrm{mg} / \mathrm{mL}$ in phosphate buffered saline (PBS); $100 \mu \mathrm{L} /$ well) was added during the last $4 \mathrm{~h}$ of incubation. The formazan crystals formed were dissolved by adding $0.1 \mathrm{M} \mathrm{HCl}$ in 2-propanol (100 $\mu \mathrm{L} /$ well) and absorption was measured using an ELISA reader (Denley WeScan, Finland) at $545 \mathrm{~nm}$ with reference filter set at $690 \mathrm{~nm}$. All cultures were set in triplicate, whereas cells incubated in complete medium or in medium containing the equivalent amount of DMSO, as well as cells incubated in the presence of doxorubicin (Sigma-Aldrich) were used as negative and positive controls, respectively. The half maximal inhibitory concentration $\left(\mathrm{IC}_{50}\right)$ was calculated according to the formula: $100\left(\mathrm{~A}_{0}-\mathrm{A}\right) / \mathrm{A}_{0}=50$, where $\mathrm{A}$ and $\mathrm{A}_{0}$ are optical densities of wells exposed to the compounds and control wells, respectively.

The compounds were tested at a concentration range of 200.0 to $6.25 \mu \mathrm{g} / \mathrm{mL}$ and the extract at 750.0 to $1.25 \mu \mathrm{g} / \mathrm{mL}$. Doxorubicin was used as a standard cytotoxic agent and showed IC $_{50}$ values $\leq$ $0.2 \mu \mathrm{M}$ in all cell lines tested. All experiments were performed at least three times.

\subsection{Flow Cytometry Analysis}

MCF-7, SKBR3 and HCT-116 cells were incubated with compound 6 and analyzed with flow cytometry following staining with annexin $\mathrm{V}$ and propidium iodide (PI). Cells were plated into 24-well plates (Greiner Bio-One; $3 \times 10^{5} / \mathrm{mL} ; 2 \mathrm{~mL} /$ well), let adhere overnight, and incubated with the mean $\mathrm{IC}_{50}$ value $(80 \mu \mathrm{g} / \mathrm{mL})$ and $40 \mu \mathrm{g} / \mathrm{mL}$ of compound 6 for $72 \mathrm{~h}$. Cells were detached with $2 \mathrm{mM}$ EDTA in Dulbecco's PBS (DPBS), harvested, centrifuged in cold PBS (1500 rpm; $5 \mathrm{~min}$ ), and stained with the Annexin V-FITC Apoptosis Detection Kit (BioLegend, Fell, Germany; cat\# 640914), according to the manufacturers' instructions. In brief, cells were resuspended in binding buffer, then annexin V-FITC $(5 \mu \mathrm{L})$ and PI ( $10 \mu \mathrm{L} ; 0.03 \mu \mathrm{g} /$ sample) were added, mixed, and incubated with the cells for $15 \mathrm{~min}$ in the dark at room temperature. The volume was adjusted to $500 \mu \mathrm{L}$ with binding buffer and the cell suspension was immediately analyzed in a FACSCanto II (BD Biosciences, San Diego, CA, USA) using FACSDiva software (V7, BD Biosciences).

\subsection{Cytotoxic Effect against Human Peripheral Blood Mononuclear Cells}

Compound 6 was additionally assessed for its cytotoxicity against human peripheral blood mononuclear cells (PBMCs) isolated from healthy blood donors' peripheral blood as previously described [30]. Prior to blood draw, individuals gave their informed consent according to the regulations approved by the 2nd Peripheral Blood Transfusion Unit and Hemophiliac Centre, "Laikon" General Hospital Institutional Review Board, Athens, Greece. PBMCs were seeded in 24-well plates $\left(5 \times 10^{5} / \mathrm{mL} ; 2 \mathrm{~mL} /\right.$ well $)$ and exposed to 2 concentrations of compound $6: 80 \mu \mathrm{g} / \mathrm{mL}$ and $40 \mu \mathrm{g} / \mathrm{mL}$. PBMCs were collected, stained as described in 2.5 and analyzed by flow cytometry.

\section{Results and Discussion}

\subsection{Secondary Metabolites Isolated from O. sanctum}

The phytochemical study of both nonpolar and polar extracts from O. sanctum aerial parts led to the isolation of 14 compounds identified on the basis of their spectra. More specifically, five terpenoids, i.e., ursolic acid (1) [31], oleanolic acid (2) [32], betulinic acid (3) [32,33], stigmasterol (4) [33], and $\beta$-caryophyllene oxide (5) [34]; two lignans, (-)-rabdosiin (6) $[35,36]$ and shimobashiric acid C (7) [37]; three flavonoids, luteolin (8) [38], its 7-O- $\beta$-D-glucuronide (9) [39-41], and apigenin 7-O- $\beta$-D-glucuronide (10) [42,43]; and phenolic compounds, (E)- $p$-coumaroyl 4-O- $\beta$-D-glucoside 
(11) [44], 3-(3,4-dihydroxyphenyl) lactic acid (12) [45], protocatechuic acid (13) [46], and vanillic acid (14) [46] were isolated. This is the first time that compounds 6, 7, 11, and $\mathbf{1 2}$ were isolated from this plant.

According to the literature, the taxonomic description of the genus Ocimum L. is still debatable. It is composed of three subgenera, namely subgenus Ocimum (comprising three sections: Ocimum, Gratissima and Hiantia), subgenus Nautochilus, and subgenus Gymnocimum. The species (O. sanctum L.) under investigation has been located in the subgenus Gymnocimum. This subgenus can be distinguished because of the existence of flavonoid glucuronides, which are found in plants of the subgenera Nautochilus and Ocimum [38]. Consequently, our work is in agreement with previous studies regarding the chemical profile of the subgenus Gymnocimum. Moreover, it was previously shown that 3-(3,4-dihydroxyphenyl) lactic acid is a precursor of the nonenzymatic synthesis of (S)-(-)-rosmarinic acid and (+)-rabdosiin [47], therefore its identification (compound 12) could be related to the biosynthesis of (-)-rabdosiin (6) [48].

Compound (-)-rabdosiin (6) (Figure 1) is a caffeic acid tetramer connected to a lignan skeleton. Originally, it has been isolated and identified from the stem of Rabdosia japonica, Labiatae [35], while both enantiomers (-)-rabdosiin and (+)-rabdosiin were later isolated from Macrotomia euchroma, Boraginaceae [49] and also from other plants of this family such as Lithospermum erythrorhizon [50] and Eritrichium sericeum [36]. Based on the fact that the entire fractionation and isolation procedures were continuously monitored by ${ }^{1} \mathrm{H}-\mathrm{NMR}$, the active compound $\mathbf{6}$ was not detected in other fractions (NMR data of $\mathbf{6}$ are provided as Supplementary Materials, Tables S1 and S2, Figures S1-S6). Consequently, being a minor compound of the plant, its activity could derive in synergy with other constituents.<smiles>Cc1ccc(C[C@@H](C)OC(=O)C2=Cc3cc(C)c(C)cc3[C@@H](c3ccc(O)c(C)c3)[C@H]2C(=O)O[C@H](C)Cc2ccc(C)c(C)c2)cc1C</smiles>

Figure 1. Chemical structures of (-)-rabdosiin (6) isolated from O. sanctum.

According to published data, rabdosiin and the similar caffeic acid derivatives have been suggested as potential anti-HIV and antiallergic agents. Moreover, studies showed that rabdosiin is an antioxidant factor (acting as an effective scavenger of reactive oxygen species), as well as a possible inhibitor of hyaluronidase and $\beta$-hexosaminidase release [51,52]. Nevertheless, to the best of our knowledge, the antiproliferative activity of rabdosiin is reported for the first time.

\subsection{Antiproliferative Activityod of Secondary Metabolites of O. sanctum}

Using the MTT dye reduction assay, the methanol:water extract (7:3) and 6 purified secondary metabolites (compounds 6, 7, 9, 11, 12, and 13) were screened for their cytotoxic/cytostatic activity against human breast and colon cell lines. Our results showed that the extract was cytotoxic against all cell lines, with an $\mathrm{IC}_{50}$ range of $45 \pm 2.12$ to $57 \pm 14.14 \mu \mathrm{g} / \mathrm{mL}$ (Table 1). Based on these data, we further proceeded to the screening of the isolated natural products $6,7, \mathbf{9}, \mathbf{1 1}, \mathbf{1 2}$, and 13 against MCF-7 cells which was the mostly affected cell line exposed to the methanol extract of $O$. sanctum $\mathrm{L}$. The $\mathrm{IC}_{50}$ values calculated are presented in Table 1 . Among the purified compounds, the most prominent was 6, which was further tested against SKBR3 and HCT-116 cells. Overall, compound 6 demonstrated 
a considerable cytotoxic activity, with $\mathrm{IC}_{50}$ values $75 \pm 2.12,83 \pm 3.54$ and $84 \pm 7.78 \mu \mathrm{g} / \mathrm{mL}$ against MCF-7, SKBR3, and HCT-116, respectively.

Table 1. In vitro cytotoxicity of the methanol extract and isolated compounds from Tulsi on human cancer cell lines.

\begin{tabular}{|c|c|c|c|c|c|c|c|c|}
\hline & \multicolumn{7}{|c|}{$\mathrm{IC}_{50} \pm \mathrm{SD}(\text { in } \mu \mathrm{g} / \mathrm{mL})^{\mathrm{a}}$} & \multirow{2}{*}{$\begin{array}{c}\mathrm{IC}_{50} \pm \mathrm{SD} \text { (in } \\
\mu \mathrm{M})\end{array}$} \\
\hline Compounds & 6 & 7 & 9 & 11 & 12 & 13 & Extract* & \\
\hline MCF-7 & $75 \pm 2.12^{\mathrm{a}}$ & $142 \pm 3.54$ & $141 \pm 1.41$ & $139 \pm 7.78$ & $140 \pm 12.02$ & $140 \pm 4.95$ & $45 \pm 2.12$ & $0.092 \pm 0.007$ \\
\hline SKBR3 & $83 \pm 3.54$ & NT & NT & NT & NT & NT & $46 \pm 5.66$ & $0.095 \pm 0.008$ \\
\hline НСТ-116 & $84 \pm 7.78$ & NT & NT & NT & NT & NT & $57 \pm 14.14$ & $0.192 \pm 0.029$ \\
\hline
\end{tabular}

* Methanol:water 70:30 a $\mathrm{IC}_{50}$ values were determined after $72 \mathrm{~h}$ of exposure to each compound and represent means \pm standard deviation (SD) of three independent experiments performed; Doxorubicin was used as positive control and showed $\mathrm{IC}_{50} \leq 0.20 \mu \mathrm{M}$ for all cell lines assayed.

To analyze the type of cell death (apoptosis or necrosis) induced by compound 6 on MCF-7, SKBR3, and HCT-116 cells, cells were stained with annexin V which binds phosphatidylserine exposed on the surface of apoptotic cells and PI which intracellulary stains the DNA of necrotic cells. As shown in Figure $2,80 \mu \mathrm{g} / \mathrm{mL}$ of compound 6 drove ca. $50 \%$ of all cells to apoptosis. Specifically, $44.9 \%$ of MCF-7 were annexin $\mathrm{V}+$ and $12.3 \%$ annexin $\mathrm{V}+/ \mathrm{PI}+$, suggesting that cells exposed to compound 6 underwent early apoptosis and a small percentage thereof late apoptosis/necrosis. Analogous percentages were obtained for SKBR3 (40.1\% early apoptotic; $9.1 \%$ late apoptotic/necrotic) and HCT-116 (43.1\% early apoptotic; $10.2 \%$ late apoptotic/necrotic) cells. When the same cell lines were exposed to $40 \mu \mathrm{g} / \mathrm{mL}$ of compound 6, the percentages of early apoptotic and late apoptotic/necrotic cells were reduced ca. by $50 \%$ (13.5-20.1\% and 3.9-6.5\%, respectively), suggesting that induction of apoptosis by compound 6 is concentration-dependent.
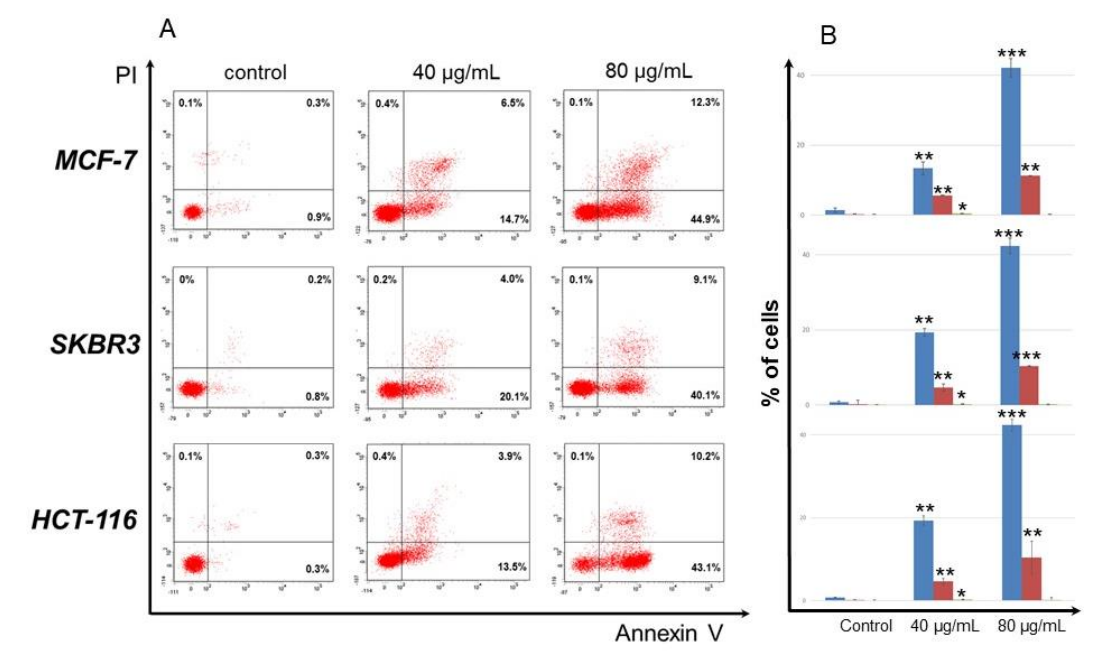

Figure 2. Compound 6 induced apoptosis to human cancer cells. MCF-7, SKBR3, and HCT-116 cells were exposed to 40 and $80 \mu \mathrm{g} / \mathrm{mL}$ of compound 6 for $72 \mathrm{~h}$, stained with annexin $\mathrm{V}$ and PI, and analyzed by flow cytometry. Control cells were incubated in complete medium supplemented with $0.5 \%$ DMSO. Flow cytometry analysis was performed using FACS Diva software. (A). Representative dot plots from cells treated with compound 6. Percentages of early apoptotic (lower right), late apoptotic/necrotic (upper right), and necrotic (upper left) are shown in each quadrat. (B). Histograms of apoptotic and necrotic cells after exposure to compound 6. Blue columns show percentages of early apoptotic, red columns of late apoptotic and green columns of necrotic cells. Mean values \pm SD from 3 experiments are shown. ${ }^{*}, p<0.05 ;{ }^{* *}, p<0.01 ;{ }^{* * *}, p<0.001$, in all cases compared to control after Student's unpaired $t$-tests. 
Based on the significant cytotoxic activity of compound 6 against cancer cell lines we further tested whether it may also be toxic against normal cells, i.e., PBMCs isolated from two different healthy blood donors. PBMCs were incubated for $24 \mathrm{~h}$ with the $\mathrm{IC}_{50}$ and the $1 / 2$ concentration of 6 , stained and analyzed by flow cytometry. Interestingly, the $\mathrm{IC}_{50}$ of compound $6(80 \mu \mathrm{g} / \mathrm{mL})$ induced early and late apoptosis/necrosis in a small percentage of PBMCs $(2.8 \%$ and $3.0 \%$ for donor $1 ; 4.3 \%$ and $3.1 \%$ for donor 2, respectively). At half concentration, the percentages were highly reduced and much less early apoptotic and late apoptotic/necrotic cells were detected (1.8\% and $1.7 \%$ for donor $1 ; 2.1 \%$ and $1.9 \%$ for donor 2, respectively) (Figure 3).

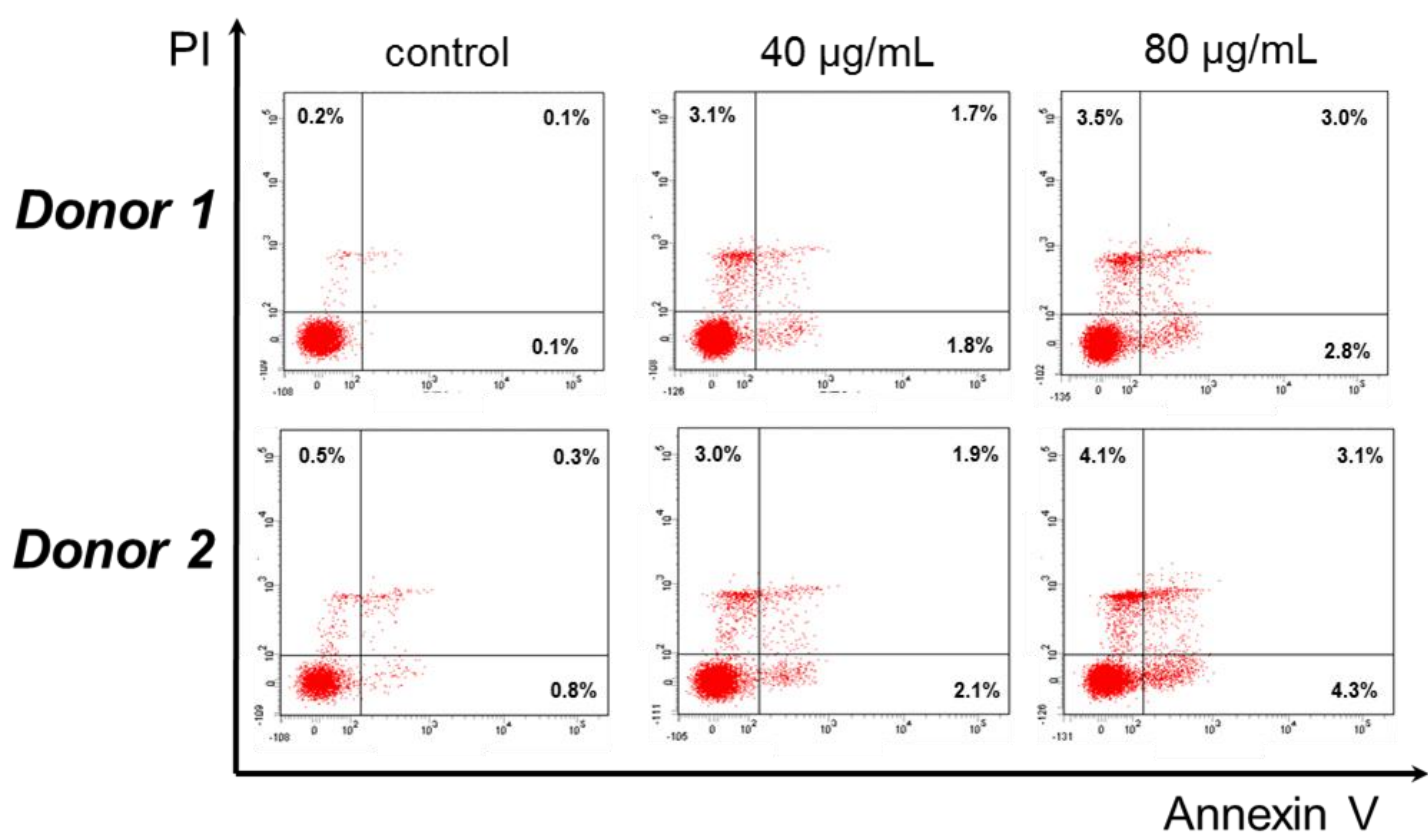

Figure 3. Compound 6 does not induce apoptosis or necrosis to peripheral blood mononuclear cells (PBMCs). PBMCs were isolated from 2 different donors (1 and 2) and incubated with 40 and $80 \mu \mathrm{g} / \mathrm{mL}$ of compound 6 for $24 \mathrm{~h}$. Other details as in Legend of Figure 2. Representative dot plots from both donors are shown from one experiment performed in duplicate.

The good antitumor activity of compound $\mathbf{6}$ against human cancer cells and the simultaneous marginal cytotoxicity of the same compound when tested against normal human cells (PBMCs), suggest that (-)-rabdosiin may display less toxic side effects when administered in vivo. In support of our results, the few studies carried out in the last decade on the potential anticancer activity of O. sanctum extracts and its essential oil with different human cancer cell lines, clearly suggest that Tulsi may be used as a supplement to enhance anticancer chemotherapy without causing severe damage to normal epithelial cells $[25,53,54]$. Botanical drugs are currently approved in therapy with specific indications and in the last decades, research has focused on the anticancer effect of plant extracts.

Taken altogether, (-)-rabdosiin displays an interesting proapoptotic activity against cancer cell lines and in parallel shows a noticeable selectivity to malignant cells. It is noteworthy that the cytotoxic response of the extract is better compared to the other isolated compounds, including compound 6 . As (-)-rabdosiin is a minor compound of the plant, we assume that it contributes to the improved antiproliferative activity of the methanol extract, and that it is probably synergistically with other active metabolites. The good activity of the polar extract, as well as of compound $\mathbf{6}$ against a series of human cancer cell lines and its marginal cytotoxicity against PBMCs, give evidence toward the effective use of this plant for the prevention of human cancer. Moreover, the core structure of (-)-rabdosiin could be considered as drug lead in anticancer drug design. 
Supplementary Materials: The following are available online at http:/ / www.mdpi.com/2305-6320/6/1/37/s1, Table S1: ${ }^{1} \mathrm{H}-\mathrm{NMR}$ of 6 (CD $\left.\mathrm{CD}, 400 \mathrm{MHz}\right)$; Table S2: ${ }^{13} \mathrm{C}-\mathrm{NMR}$ of 6 (CD $\left.3 \mathrm{OD}, 400 \mathrm{MHz}\right)$; Figure S1: ${ }^{1} \mathrm{H}-\mathrm{NMR}$ spectrum of $6\left(\mathrm{CD}_{3} \mathrm{OD}, 400 \mathrm{~Hz}\right)$; Figure S2: COSY spectrum of $6\left(\mathrm{CD}_{3} \mathrm{OD}, 400 \mathrm{~Hz}\right)$; Figure S3: ${ }^{13} \mathrm{C}$ NMR spectrum of $6\left(\mathrm{CD}_{3} \mathrm{OD}, 400 \mathrm{~Hz}\right)$; Figure S4: HSQC spectrum of $6\left(\mathrm{CD}_{3} \mathrm{OD}, 400 \mathrm{~Hz}\right)$; Figure S5: HMBC spectrum of $6\left(\mathrm{CD}_{3} \mathrm{OD}\right.$, $400 \mathrm{~Hz}$ ); Figure S6: Most important HMBC signals of compound 6.

Author Contributions: Investigation, A.F., T.M.I., and P.S.; Supervision, O.T. and H.S.; Writing-Original Draft, C.B.

Funding: This research received no external funding.

Conflicts of Interest: The authors declare no conflicts of interest.

\section{References}

1. Prajapati, N.D.; Purohit, S.S.; Sharma, A.K.; Kumar, T.A. Hand Book of Medicinal Plant, 1st ed.; Agrobios: Jodhpur, India, 2003; p. 367.

2. Cohen, M.M. Tulsi-Ocimum sanctum: A herb for all reasons. J. Ayurveda Integr. Med. 2014, 5, $251-259$. [CrossRef] [PubMed]

3. Pandey, B. Anita. In Economic Botany; Chand and Company Ltd.: New Delhi, India, 1990; p. 294.

4. Rajeshwari, S. Ocimum sanctum: The Indian home remedy. In Current Medical Scene; Cipla Ltd.: Bombay, India, 1992.

5. Gupta, S.K.; Prakash, J.; Srivastava, S. Validation of traditional claim of Tulsi, Ocimum sanctum Linn. as a medicinal plant. Indian J. Exp. Biol. 2002, 40, 765-773.

6. Das, S.K.; Vasudevan, D.M. Tulsi: The Indian holy power plant. Nat. Prod. Radiance 2006, 5, $279-283$.

7. Mondal, S.; Mirdha, B.R.; Mahapatra, S.C. The Science behind sacredness of Tulsi (Ocimum sanctum L.). Indian J. Physiol. Pharmacol. 2009, 53, 291-306. [PubMed]

8. Pandey, G.; Madhuri, S. Pharmacological activities of Ocimum sanctum (Tulsi): A review. JPSR 2010, 5, 61-66.

9. Mohan, L.; Amberkar, M.V.; Kumari, M. Ocimum sanctum linn (TULSI)—An overview. JPSR 2011, 7, 51-53.

10. Pattanayak, P.; Pritishova, B.; Debajyoti, D.; Panda, S.K. Ocimum sanctum Linn. A reservoir plant for therapeutic applications: An overview. Pharmacogn. Rev. 2010, 4, 95-105. [CrossRef] [PubMed]

11. Khanna, N.; Bhatia, J. Antinociceptive action of Ocimum sanctum (Tulsi) in mice: Possible mechanisms involved. J. Ethnopharmacol. 2003, 88, 293-296. [CrossRef]

12. Babu, K.; Uma Maheswari, K.C. In vivo studies on the effect of Ocimum sanctum L. leaf extract in mordifying the genotoxicity induced by chromium and mercury in Allium root meristems. J. Environ. Biol. 2006, 27, 93-95.

13. Narendhirakannan, R.T.; Subramanian, S.; Kandaswamy, M. Biochemical evaluation of antidiabetogenic properties of some commonly used Indian plants on streptozotocin-induced diabetes in experimental rats. Clin. Exp. Pharmacol. Physiol. 2006, 33, 1150-1157. [CrossRef]

14. Hannan, J.M.; Marenah, L.; Ali, L.; Rokeya, B.; Flatt, P.R.; Abdel-Wahab, Y.H. Ocimum sanctum leaf extracts stimulate insulin secretion from perfusd pancreas, isolated islets and clonal pancreatic beta-cells. J. Endocrinol. 2006, 189, 127-136. [CrossRef] [PubMed]

15. Grovel, J.K.; Vats, V.; Yadav, S.S. Pterocarpus marsupium extract (Vijayasar) prevented the alteration in metabolic patterns induced in the normal rat by feeding an adequate diet containing fructose as sole carbohydrate. Diabetes Obes. Metab. 2005, 7, 414-420. [CrossRef] [PubMed]

16. Suzuki, A.; Shirota, O.; Mori, K.; Sekita, S.; Fuchino, H.; Takano, A.; Kuroyanagi, M. Leishmanicidal active constituents from Nepalese medicinal plant Tulsi (Ocimum sanctum L.). Chem. Pharm. Bull. 2009, 57, 245-251. [CrossRef] [PubMed]

17. Jamshidi, J.; Cohen, M.M. The Clinical Efficacy and Safety of Tulsi in Humans: A Systematic Review of the Literature. Evid. Based Complement. Altern. Med. 2017. [CrossRef] [PubMed]

18. Available online: http://www.himalayawellness.com/herbfinder/ocimum-tenuiflorum.htm (accessed on 31 January 2019).

19. Skaltsa, H.; Tzakou, O.; Singh, M. Polyphenols of Ocimum sanctum L. from Suriname. Pharm. Biol. 1999, 37, 92-94. [CrossRef]

20. Skaltsa, H.; Couladi, M.; Philianos, S.; Singh, M. Phytochemical Study of the leaves of Ocimum sanctum L. Fitoterapia 1987, 4, 286. 
21. Skaltsa, H.; Tzakou, O.; Loukis, A.; Argyriadou, N. Analyse de l'huile essentielle d'Ocimum sanctum L. Plant. Méd. Phytoth. 1990, 2, 79-81.

22. Kumar, S.; Pandey, A.K. Chemistry and Biological Activities of Flavonoids: An Overview. Sci. World J. 2013. [CrossRef]

23. Desai, S.; Desai, D.G.; Kaur, H. Saponins and their biological activities. Pharma Times 2009, 41, 13-16.

24. Bezerra, D.P.; Militão, G.C.G.; Castro de Morais, M.; Pergentino de Sousa, D. The Dual Antioxidant/Prooxidant Effect of Eugenol and Its Action in Cancer Development and Treatment. Nutrients 2017, 9, 1367. [CrossRef]

25. Manaharan, T.; Thirugnanasampandan, R.; Jayakumar, R.; Kanthimathi, M.S.; Ramya, G.; Gogul Ramnath, M. Purified essential oil from Ocimum sanctum Linn. triggers the apoptotic mechanism in human breast cancer cells. Pharmacogn. Mag. 2016, 12, S327-S331.

26. Mabry, T.G.; Markham, K.R.; Thomas, M.B. The Systematic Identification of Flavonoids; Springer Science \& Business Media: Berlin/Heidelberg, Germany; New York, NY, USA, 1970.

27. Coll, J.C.; Bowden, B.F. The application of Vacuum Liquid Chromatography to the separation of terpene mixtures. J. Nat. Prod. 1986, 49, 934-936. [CrossRef]

28. Neu, R. Chelate von Diarylborsäuren mit aliphatischen oxyalkylaminen als reagenzien für den nachweis von oxyphenyl-benzo- $\gamma$-pyronen. Die Naturwissenchaften 1957, 44, 181. [CrossRef]

29. Mosman, T. Rapid colorimetric assay for cellular growth and survival: Application to proliferation and cytotoxicity assays. J. Immunol. Methods 1983, 65, 55-63. [CrossRef]

30. Ioannou, K.; Derhovanessian, E.; Tsakiri, E.; Samara, P.; Kalbacher, H.; Voelter, W.; Trougakos, I.P.; Pawelec, G.; Tsitsilonis, O.E. Prothymosin $\alpha$ and a prothymosin $\alpha$-derived peptide enhance TH1-type immune responses against defined HER-2/neu epitopes. BMC Immunol. 2013, 14, 43-55. [CrossRef]

31. Liu, J. Pharmacology of oleanolic acid and ursolic acid. J. Ethnopharmacol. 1995, 49, 57-58.

32. Moghaddam, G.M.; Ahmad, F.; Samzadeh-Kermani, A. Biological Activity of Betulinic Acid: A Review. Pharmacol. Pharm. 2012, 3, 119-123. [CrossRef]

33. Batta, A.K.; Xu, G.; Honda, A.; Miyazaki, T.; Salen, G. Stigmasterol reduces plasma cholesterol levels and inhibits hepatic synthesis and intestinal absorption in the rat. Metabolism 2006, 55, 292-299. [CrossRef] [PubMed]

34. Ghelardini, C.; Galeotti, N.; Di Cesare, L.; Mazzanti, G.; Bartolini, A. Local anaesthetic activity of $\beta$-caryophyllene. Farmaco 2001, 56, 5-7. [CrossRef]

35. Agata, I.; Hatanp, T.; Okudaq, T.A. Tetrameric derivative of caffeic acid from Rabdosia japonica. Phytochemistry 1989, 28, 2447-2450. [CrossRef]

36. Inyushkina, V.Y.; Bulgakov, P.V.; Veselova, V.M.; Bryukhanov, M.V.; Zverev, F.Y.; Lampatov, V.V.; Azarova, V.O.; Tchernoded, K.G.; Fedoreyev, A.S.; Zhuravlev, N.Y. High Rabdosiin and Rosmarinic acid production in Eritrichium sericeum callus cultures and the effect of the calli on Masugi-Nephritis in rats. Biosci. Biotechnol. Biochem. 2007, 71, 1286-1293. [CrossRef]

37. Murata, T.; Miyase, T.; Yoshizaki, F. Hyalurodinase inhibitors from Keiskea japonica. Chem. Pharm. Bull. 2008, 60, 121-128. [CrossRef]

38. López-Lázaro, M. Distribution and biological activities of the flavonoid luteolin. Mini Rev. Med. Chem. 2009, 9, 31-59. [CrossRef] [PubMed]

39. Grayer, R.J.; Kite, G.C.; Veitch, N.C.; Eckert, M.; Marin, P.D.; Senanayake, P.; Paton, A.J. Leaf flavonoid glycosides as chemosystematic characters in Ocimum. Biochem. Syst. Ecol. 2002, 30, 327-342. [CrossRef]

40. Markham, R.K.; Porter, J.L.; Mues, R.; Zinsmeister, D.H.; Brehmm, G.B. Flavonoid variation in the liverwort Conocephalum conicum: Evidence for geographic races. Phytochemistry 1976, 15, 147-150. [CrossRef]

41. Lu, Y.; Foo, L.Y. Flavonoid and phenolic glycosides from Salvia officinalis. Phytochemistry 2000, 55, $263-267$. [CrossRef]

42. Agrawal, P.K.; Bansal, M.C. Flavonoid glycosides. In Carbon-13 NMR of Flavonoids; Agrawal, P.K., Ed.; Elsevier: Amsterdam, The Netherlands, 1989; pp. 283-364.

43. Markham, K.R.; Geiger, H. ${ }^{1} \mathrm{H}$ NMR spectroscopy of flavonoids and their glycosides in DMSO-d6. In The Flavonoids, Advances in Research Since 1986; Harborne, J.B., Ed.; Chapman and Hall: London, UK, 1994; pp. 441-497.

44. Foo, L.Y.; Molan, A.L.; Woodfield, D.R.; McNabb, W.C. The phenols and prodelphinidins of white cover flowers. Phytochemistry 2000, 54, 539-548. [CrossRef] 
45. Yahara, S.; Satoshiro, M.; Nishioka, I.; Nagasawa, T.; Oura, H. Isolation and Characterization of Phenolic Compounds from Coptidis Rhizoma. Chem. Pharm. Bull. 1985, 33, 527. [CrossRef]

46. Norr, H.; Wagner, H. New constituents from Ocimum sanctum. Planta Med. 1992, 58, 574. [CrossRef]

47. Bogucki, D.; Charlton, J. A non-enzymatic synthesis of (S)-(-)-rosmarinic acid and a study of a biomimetic route to (+)-rabdosiin. Can. J. Chem. 1997, 75, 1783-1794. [CrossRef]

48. Agata, I.; Hatano, T.; Nishibe, S.; Okuda, T. Rabdosiin, a new rosmarinic acid dimer with a lignan skeleton, from Rabdosia japonica. Chem. Pharm. Bull. 1988, 36, 3223-3225. [CrossRef]

49. Nishizawa, M.; Tsuda, M.; Hayashi, K. Two caffeic acid tetramers having enantiomeric phenyldihydronaphthalene moieties from Macrotomia euchroma. Phytochemistry 1990, 29, 2645-2649. [CrossRef]

50. Yamamoto, H.; Inoue, K.; Yazaki, K. Cafeic acid oligomers in Lithospermum erythrorhizon cell suspension cultures. Phytochemistry 2000, 53, 651-657. [CrossRef]

51. Ito, H.; Miyazaki, T.; Ono, M.; Sakurai, H. Antiallergic activities of rabdosiin and its related compounds: Chemical and biochemical evaluations. Bioorg. Med. Chem. 1988, 6, 1051-1056. [CrossRef]

52. Kashiwada, Y.; Nishizawa, M.; Yamagishi, T.; Tanaka, T.; Nonaka, G.; Cosentino, L.M.; Snoder, J.V.; Lee, K. Anti-AIDS agents, 18. Sodium and potassium salts of caffeic acid tetramers from Arnebia euchromaas anti-HIV agents. J. Nat. Prod. 1995, 58, 392-400. [CrossRef] [PubMed]

53. Dhandayuthapani, S.; Azad, H.; Rathinavelu, A. Apoptosis Induction by Ocimum sanctum extract in LNCaP prostate cancer cells. J. Med. Food 2015, 18, 776-785. [CrossRef] [PubMed]

54. Bhattacharyya, P.; Bishayee, A. Ocimum sanctum Linn. (Tulsi): An ethnomedicinal plant for the prevention and treatment of cancer. Anticancer Drugs 2013, 24, 659-666. [CrossRef] [PubMed]

(C) 2019 by the authors. Licensee MDPI, Basel, Switzerland. This article is an open access article distributed under the terms and conditions of the Creative Commons Attribution (CC BY) license (http:/ / creativecommons.org/licenses/by/4.0/). 